ISSN 0103-9954

\title{
THE USE OF CONTINUOUS, TEMPORARY IMMERSION BIOREACTOR SYSTEM AND SEMISOLID CULTURE MEDIUM FOR THE PRODUCTION Of Eucalyptus camaldulensis CLONES
}

\author{
USO DE BIORREATORES DE IMERSÃO CONTINUA, TEMPORÁRIA E MEIO DE CULTURA \\ SEMISSÓLIDO NA PRODUÇÃO DE CLONES DE Eucalyptus camaldulensis
}

\author{
Evânia Galvão Mendonça ${ }^{1}$ Vanessa Cristina Stein ${ }^{2}$ Humberto Henrique de Carvalho ${ }^{3}$ \\ Breno Régis Santos ${ }^{4}$ Luiz Alberto Beijo ${ }^{5}$ Luciano Vilela Paiva ${ }^{6}$
}

\begin{abstract}
The plant micro-propagation in bioreactor systems is regarded as one way to reduce cost by automation and production scheduling. This research was carried out in order to obtain an efficient procedure for clone production of Eucalyptus camaldulensis on different types of bioreactor including continuous and temporary immersion bioreactor. To do so, the apical meristems $(1 \mathrm{~mm})$ and the apical meristems with adjacent tissue $(2,5 \mathrm{~mm})$ were used as initial explants. These tissues were cultured, for 60 days, in semisolid culture medium supplemented with $1 \mathrm{mg} \mathrm{L}^{-1}$ indole acetic acid (IAA) and $0.32 \mathrm{mg} \mathrm{L}^{-1}$ benzylaminopurine (BA). After 60 days, the meristems with adjacent tissue were transferred to a continuous immersion bioreactor and maintained in dark or light conditions. In order to verify the effect of the explant source on bioreactor multiplication, the explants subcultured from meristems multiplied in semisolid culture medium and the meristems multiplied in continuous immersion bioreactor were tested and maintained in dark conditions. After establishing this parameters, the multiplication experiments were carried out in continuous and temporary immersion and the multiplied explants were then rooted in MS medium supplemented with $0,2,4,8$ and $20 \mathrm{mg} \mathrm{L}^{-1}$ indole butyric acid (IBA) and kept in the dark or under controlled lighting conditions. After that, the rooting the plants were acclimatized in mist chamber. The meristem with adjacent tissue favored a greater number of buds/explants. The continuous immersion bioreactor in the dark provided higher shoots number and multiplication rate. The rooting was better on culture medium without auxin and kept in the dark for 15 days or the culture medium supplemented with auxin and maintained under light with $100 \%$ plantlet rooting. The Eucalyptus camaldulensis acclimatization was efficient, with high survival rate (76\%). It was possible to establish the procedure for bioreactor micro-propagation of Eucalyptus camaldulensis large-scale clones.
\end{abstract}

Keywords: meristems; culture media; adventitious rooting.

1 Engenheira Florestal, Dr $^{\mathrm{a}}$., Professor Adjunto do Departamento de Floresta, Instituto Florestal, Universidade Federal Rural do Rio de Janeiro, Rod. BR 465 - $\mathrm{km} \mathrm{7,} \mathrm{Campus} \mathrm{Universitário,}$ CEP 23851-970, Seropédica (RJ), Brasil. evaniafloresta@hotmail.com

2 Bióloga, Dra., Professor Adjunto da Universidade Federal de São João Del-rei, Campus CentroDona Lindu - CCO, Av. Sebastião Gonçalves Coelho, 400, CEP 35500-000, Divinópolis (MG). Brasil. vanessastein@ufsj.edu.br

3 Biólogo, Dr., Professor Adjunto do Departamento de Bioquímica e Biologia Molecular da Universidade Federal do Ceará, Av. da Universidade, 2853 - Benfica, CEP 60020-180, Fortaleza - CE. Brasil. Humberto_henriquec@hotmail.com

4 Engenheiro Agrônomo, Dr., Professor Assistente do Instituto de Ciências Naturais, Universidade Federal de Alfenas, Rua Gabriel Monteiro da Silva, 714, Centro, CEP 37130-000, Alfenas (MG), Brasil. brenors@yahoo.com.br

5 Licenciado em Matemática, Dr., Professor Assistente do Departamento de Ciências Físicas, Universidade Federal de Alfenas, Rua Gabriel Monteiro da Silva, 714, Centro, CEP 37130-000, Alfenas (MG), Brasil. prof.beijo@gmail.com

6 Engenheiro Agrônomo, Dr., Professor Assistente do Departamento de Química, Universidade Federal de Lavras, Câmpus Universitário, Caixa Postal 37, CEP 37200-000, Lavras (MG), Brasil. luciano@dqi.ufla.br

Recebido para publicação em 23/06/2014 e aceito em 25/02/2015

Ci. Fl., v. 26, n. 4, out.-dez., 2016 


\section{RESUMO}

A micropropagação em sistemas de biorreatores é considerada como uma forma de reduzir os custos de produção por meio do escalonamento de automatização do processo. O objetivo desse trabalho foi desenvolver um protocolo eficiente de produção de mudas de Eucalyptus camaldulensis em diferentes tipos de sistema, incluindo biorreator de imersão continua e temporária. Para isso, meristemas apicais (1 mm) e meristemas apicais com tecido adjacente $(2,5 \mathrm{~mm})$ foram usados como explantes iniciais. Esses tecidos foram cultivados, por 60 dias, em meio de cultura suplementado com $1 \mathrm{mg} \mathrm{L}^{-1}$ de ácido indolacético (AIA) e $0.32 \mathrm{mg} \mathrm{L}^{-1}$ de benzilaminopurina (BAP). Após 60 dias, os meristemas com tecidos adjacentes foram transferidos para biorreatores de imersão contínua ou temporária e mantidos no escuro ou sob condições controladas de luminosidade. Para verificar o efeito da fonte de explante na multiplicação em biorreator foram testados explantes subcultivados de meristemas multiplicados em meio de cultura semissólido e meristemas multiplicados em biorreator de imersão contínua e mantidos no escuro. Despois de estabelecer esses parâmetros, os experimentos de multiplicação foram realizados em biorreatores de imersão contínua e temporária. Os explantes multiplicados foram enraizados em meio de cultura MS suplementado com $0,2,4,8$ e $20 \mathrm{mg} \mathrm{L}^{-1}$ de ácido indolbutírico (AIB) e mantidos no escuro ou sob condições controladas de luminosidade. Depois do enraizamento as plantas foram aclimatizadas em câmara de nebulização. Os meristemas com tecidos adjacentes favoreceram um maior número de gemas/explantes. O biorreator de imersão contínua e mantido no escuro promoveu maior número de brotações e maior taxa de multiplicação e o melhor enraizamento ocorreram no meio de cultura isento de auxina, mantido no escuro por 15 dias ou o meio de cultura suplementado com auxina, mantido na luz apresentando $100 \%$ de enraizamento. A aclimatização do Eucalyptus camaldulensis foi eficiente com taxa de sobrevivência de $76 \%$. Portanto, foi possível desenvolver um método eficiente de micropropagação em biorreator para a produção de mudas Eucalyptus camaldulensis em larga escala.

Palavras-chave: meristemas; meio de cultura; enraizamento adventício.

\section{INTRODUCTION}

Brazil has dramatically increased the productivity of exotic Eucalyptus plantations (STAPE et al., 2004) but little is known about the physiological processes that control growth and their regulation. We examined the main environmental factors controlling growth and resource use across a geographic gradient with clonal Eucalyptus grandis $\mathrm{X}$ Eucalyptus urophylla in north-eastern Brazil. Rates of production and resource use were estimated for 14 stands that spanned a four-fold range in production. The supply of water appeared to be the most limiting resource in these fertilized plantations. Above-ground net primary production (ANPP. Over the 35 years, the intensive researches tripled the Eucalyptus average yields in almost 4 million ha through seed selection and clonal propagation and improved silviculture techniques (fertilization and control of ants and weeds) (GONÇALVES et al., 2008). Along with this, the Brazilian Eucalyptus plantations are now ones of the most productive crops in the world, with mean growth rates of 25 $\mathrm{m} 3 \mathrm{ha}^{-1}$ year $^{-1}\left(50 \mathrm{~m}^{3} \mathrm{ha}^{-1}\right.$ year $^{-1)}$ and with over the 4.7 million planted hectares (BINKLEY et al., 2010) and these Eucalyptus production is used to produce energy, pulp, paper and others. Moreover, the Eucalyptus is rich in essential oils widely used in the pharmaceutical and cosmetics industry (HU et al., 1999; TOURNIER, 2003).

The high yields in Eucalyptus plantations result not only from silviculture and superior genetics but mainly from clonal plant propagations. The clonal propagation methods for Eucalyptus are based on macro, micro-cutting (XAVIER; COMÉRCIO, 1996) and mini-cuttings (XAVIER; WENDLING, 1998; ASSIS et al., 2004; BRONDANI et al., 2012), but such cutting presents some problems (XAVIER; COMÉRCIO, 1996) as low rooting capacity of some clones and limited availability of shoots and nodes (ASSIS et al., 2004).

The plant production by micro-propagation is an alternative method, offering advantages over mini-cutting (KOMATSU et al., 2011), such as: high multiplication rate, high rooting rate; plant health, ensuring the absence of pests and diseases; environmental control and lower demand of physical space (ANDRADE et al., 2006). But, despite the 
potential advantages of micro-propagation, the in vitro multiplication has been used primarily for the production of parent plants due to the genotypic clone variation that requires clone-specific protocols (WATT, 2014).

The micro-propagation can be initiated through the meristem culture that has been extensively used in agamic propagation, due to the multiplication rate and the genetic meristem cell stabilities (PASSOS et al., 1985). Furthermore, the micro-propagation with bioreactors technology is used to improve the large-scale micro-propagation in laboratories and bio-factories. While conventional micro-propagation uses small flasks, with a small number of plants/flasks and requires intense culture manipulation involving a large amount of skilled work, the bioreactor uses large bottles containing liquid medium with large amounts of plants, which reduces significantly the demand of skilled operators (TAKAYAMA; AKITA, 1994), and makes possible the automatic control of the bioreactors by computers (SILVA et al., 2007).

The bioreactors can be divided into two systems: temporary and continuous immersion. In the continuous immersion, the explants are always in contact with the culture medium, while in the temporary immersion the bioreactor consists of two glasses or plastic vessels, one contains the plant material (plant culture vessel) and the other stores the culture medium. The main advantages of the bioreactors in the plant propagation process include: the liquid medium is in contact with the entire surface of the explants (leaves, roots; etc.) increasing the absorption surface of nutrients and growth regulators; the aeration provides excellent oxygen supply and prevents the buildup of harmful gases, resulting in a better crop growth; the movement of explants inside the bioreactor results in reduced apical dominance expression, favoring the proliferation of axillary buds; significant reduction in manpower due to the lower handling, labeling, etc. and the production of a large number of seedlings, favoring large scale production (LIMA et al., 2011).

After the multiplication in bioreactors, the plants should be rooted and acclimatized to be cultivated in the field. In most cases, the extra expense with in vitro rooting can be justified by the reduced losses during the acclimatization and better quality of the seedlings (GEORGE et al., 1996). The rooting may occur only with the transfer of the explant to a culture medium without growth regulators, but, according to TANTOS et al. (2001), severe treatments with auxin, in high concentrations during a reduced period can be more effective. In face of the time-consuming and labour-intensive, the propagators and laboratory managers in the industry are faced with the decision of whether to optimize the protocol for each clone in the production or to use a general protocol and accept lower yields (or compensate by initiating more material) (WATT, 2014).

Hence, the aim of this study was establishing Eucalyptus camaldulensis bioreactor propagation suitable for commercial activities.

\section{MATERIALS AND METHODS}

\section{SHOOT MULTIPLICATION EXPERIMENTS}

\section{Shoot multiplication on semisolid medium}

Eucalyptus camaldulensis plants originated from adult material in vitro and grown for 35 days were used as source of meristems. The apex meristems with about $1 \mathrm{~mm}$ (isolated meristem) and about $2.5 \mathrm{~mm}$ (meristem with adjacent tissue) in length were excised using the stereomicroscope.

To induce the meristems multiplication, the isolated meristem and the meristem with adjacent tissue were inoculated on culture MS medium (MURASHIGE; SKOOG, 1962), supplemented with $20 \mathrm{~g} \mathrm{~L}^{-1}$ sucrose, $1 \mathrm{mg} \mathrm{L}^{-1}$ indoleacetic acid (IAA) and $0.32 \mathrm{mg} \mathrm{L}^{-1}$ benzylaminopurine (BA). The culture medium was solidified with $4.5 \mathrm{~g} \mathrm{~L}^{-1}$ agar $\left(\right.$ Sigma $^{\circledR}$ ) before autoclaving $121{ }^{\circ} \mathrm{C}, \approx 1 \mathrm{kgf}$ $\mathrm{cm}^{-2}$ for 20 minutes. This culture medium has been established in laboratory LCBM-UFLA for the eucalyptus micro-propagation (unpublished data). After inoculation, the explants were kept in a growth chamber for 16 hours of photoperiod and with irradiance of $40 \mu \mathrm{mol} \mathrm{m}{ }^{-2} \mathrm{~s}^{-1}$ provided by cool white light at the temperature of $27 \pm 2^{\circ} \mathrm{C}$.

The experimental design was completely randomized in split plot, with 4 replicates per treatment, each replicate consisting of 6 meristems, with a total of 24 explants per treatment. The shoots/ explants average number, the oxidation and the survived explant numbers were observed at 15,30 and 60 days of cultivation. The data were subjected to a variance analysis (ANOVA) and Scott \& Knott test at $5 \%$ of significance level for treatment means comparison (FERREIRA, 2011).

For all experiments were performed the 
Shapiro-Wilk (SHAPIRO; WILK, 1965) test to verify the normality of the residuals and the Bartlett (BARTLETT, 1937) test to check homogeneity of variances. The cases where the assumptions are met, the waste was normal and the variances were homogeneous, the analysis of variance was conducted by the Scott \& Knott test and/or regression (in the case of quantitative treatments). The cases in which the assumptions are not met, we used the non-parametric Mann-Whitney test (FERREIRA, 2011).

\section{Shoot multiplication in bioreactors}

\section{Bioreactor designing}

The continuous and temporary immersion bioreactors with $500 \mathrm{~mL}$ translucent glass bottles were used for this experiment. The continuous immersion bioreactor had two openings, one was used for the sterile air intake and other for the sterile air output. The sterile air was injected on glass bottles by a silicone tube linked to a Millipore membrane filter of $0.22 \mathrm{~mm}$ and a compressor with a capacity of $4 \mathrm{~L} \mathrm{~min}^{-1}$. The layout of the continuous immersion bioreactor prototype (Figure 1A).

In the temporary immersion bioreactor two glass bottles interconnected by silicone tubes were used. One bottle contained a culture medium and the other one of the explants (Figure 1B). In this system, sterile air was injected into the culture medium bottles to transfer, by pressure, the culture medium to the explant bottles and after a set time the sterile air was injected into the explant bottles to transfer, by

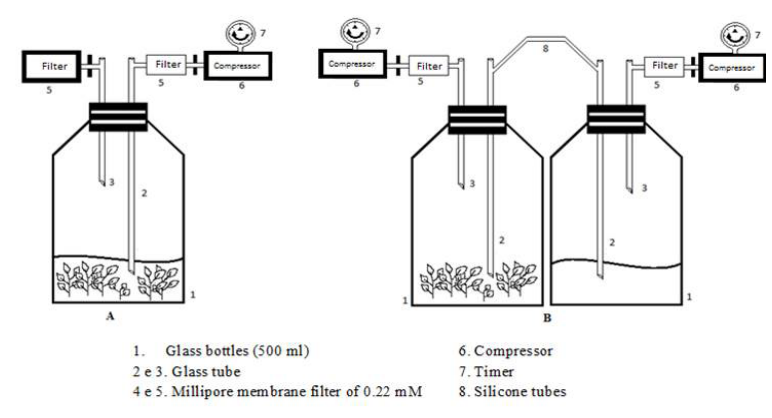

FIGURE 1: Schematic of bioreactors. (A) Continuous immersion bioreactors. (B) Temporary immersion bioreactors.

FIGURA 1: Esquema dos biorreatores. (A) Biorreator de imersão contínua. (B) Biorreator de imersão temporária. pressure, the culture medium to the culture medium bottles. The sterile air was injected in glass bottles by a silicone tube linked to a Millipore membrane filter of $0.22 \mathrm{~mm}$ and a compressor with a capacity of $4 \mathrm{~L} \mathrm{~min}^{-1}$. The frequency and immersion time were regulated by 'analogic timers' (Figure 1B).

\section{Temporary and continuous immersion bioreactor systems: effect on shoots multiplication}

In order to evaluate the efficiency of continuous and temporary immersion bioreactor systems, 21 explants with $1 \mathrm{~cm}$ length and two buds, excised from multiplied meristems, were placed in glass bottles contained $300 \mathrm{~mL}$ of liquid MS culture medium supplemented with $30 \mathrm{~g} \mathrm{~L}^{-1}$ sucrose and autoclaved for 20 minutes at $121^{\circ} \mathrm{C}$ and $\approx 1 \mathrm{kgf}$ $\mathrm{cm}-2$. The continuous immersion bioreactor in the dark (CIBD) was installed as in the previous experiment and the temporary immersion bioreactor in the dark (TIBD) was scheduled to prompt the immersion and the aeration during 15 minutes every 2 hours (adapted from SILVA et al., 2007). Both bioreactors were placed in a dark growth room with temperature of $27 \pm 2^{\circ} \mathrm{C}$.

After 15 days, these parameters were evaluated: shoot numbers, bud numbers and shoot lengths. The experiment design was completely randomized and the treatments effects for the variables were analyzed by Mann-Whitney (FERREIRA, 2011).

\section{Continuous immersion bioreactors: effect of the light on the shoot multiplications}

The explants with $1 \mathrm{~cm}$ length and two buds, excised from multiplied meristems, were placed on glass bottles contained $300 \mathrm{~mL}$ of liquid MS culture medium supplemented with $30 \mathrm{~g} \mathrm{~L}^{-1}$ sucrose, without growth regulator, autoclaved for 20 minutes at $121^{\circ} \mathrm{C}$ and $\approx 1 \mathrm{kgf} \mathrm{cm}^{-2}$.

In order to evaluate the influence of light and of dark, on the oxidation of explants, the continuous immersion bioreactors, containing the 21 explants were maintained under 16 hours of photoperiod (continuous immersion bioreactors under light - CIBL) or in the dark (continuous immersion bioreactors in the dark - CIBD) and placed a growth room with temperature of $27 \pm 2^{\circ}$ C. After 15 days, these parameters were evaluated: shoot numbers, bud numbers and shoot lengths. The experimental design was completely randomized and the treatment effects for the variable shoots 
and bud numbers were analyzed by Mann-Whitney (FERREIRA, 2011).

\section{Continuous immersion bioreactors: effect of the explant source on shoot multiplications}

Two explant sources were used: explants sub-cultured from continuous immersion bioreactors (ESCIBD) and explants excised from multiplied meristems (EMCIBD). The explants (ESCIBD and EMCIBD) with $1 \mathrm{~cm}$ length and two buds, were placed in glass bottles contained $300 \mathrm{~mL}$ of liquid MS culture medium supplemented with $30 \mathrm{~g} \mathrm{~L}^{-1}$ sucrose and autoclaved for 20 minutes at $121^{\circ} \mathrm{C}$ and $\approx 1 \mathrm{kgf} \mathrm{cm}^{-2}$.

The continuous immersion bioreactor was installed as in the previous experiment and placed in a dark growth room with temperature of 27 $\pm 2^{\circ} \mathrm{C}$. After 15 days, the following parameters were evaluated: shoot numbers, bud numbers and shoot lengths. The experiment design was completely randomized and the treatments effects for the variables were analyzed by Mann-Whitney (FERREIRA, 2011).

\section{ROOTING EXPERIMENT}

\section{Auxin effects on in vitro rooting}

Two treatments were carried out to evaluate the auxin effects. The explants were pretreated with auxin solutions or the explants were inoculated in culture medium containing auxins.

For the auxin pre-treatment experiment, the multiplied shoots with about $4.0 \mathrm{~cm}$ length were individualized and pretreated for 12 hours on $20 \mathrm{mg} \mathrm{L}^{-1}$ IBA solution and then inoculated in hormone-free MS culture medium supplemented with $30 \mathrm{~g} \mathrm{~L}^{-1}$ sucrose and solidified with $4.5 \mathrm{~g} \mathrm{~L}^{-1}$ agar $\left(\right.$ Sigma $\left.^{\circledR}\right)$ and maintained for 15 days in a dark growth chamber with temperature of $27 \pm 2^{\circ} \mathrm{C}$ and then transferred to the light (T5). For the auxin experiment the multiplied shoots with about $4,0 \mathrm{~cm}$ length were individualized and transferred to MS culture medium supplemented with $30 \mathrm{~g} \mathrm{~L}^{-1}$ sucrose, solidified with $4.5 \mathrm{~g} \mathrm{~L}^{-1}$ agar $\left(\right.$ Sigma $\left.^{\circledR}\right)$ and containing indole butyric acid (IBA) at concentrations of $0,2,4$ and $8 \mathrm{mg} \mathrm{L}^{-1}$.

Also, in order to observe the light influence on the rooting, one set of explants (T1, T2, T3, T4, and T5) were maintained for 15 days in dark growth chamber, with temperature of $27 \pm 2^{\circ} \mathrm{C}$ and then transferred to the light. The other set of explants (T6, T7, T8, T9) were maintained in a growth chamber under 16 hours of photoperiod with irradiance of $40 \mu \mathrm{mol} \mathrm{m} \mathrm{m}^{-2} \mathrm{~s}^{-1}$ provided by cool white light and temperature of $27 \pm 2^{\circ} \mathrm{C}$ throughout the experiment.

The experimental design was completely randomized with nine treatments and two replicates, each replicate consisting of five seedlings. At 30 days, each explant was evaluated by the root average number, root average length, shoot average length and leaf numbers. The program Sisvar 4.3 (FERREIRA, 2011) was used for the variance analyses (ANOVA) and the averages were compared by the Scott \& Knott test at 5\% probability.

\section{ACCLIMATIZATION}

The explants were transferred to polyethylene tubes $\left(56 \mathrm{~cm}^{3}\right)$ containing Topstrato ${ }^{\circledR}$ rooting substrate autoclaved. After planting, the tubes were transferred to a mist chamber maintained with $90 \%$ of relative humidity, $31^{\circ} \mathrm{C}$ temperature and 12 hours of photoperiod with irradiance 120 $\mu \mathrm{mol} \mathrm{m} \mathrm{m}^{-2} \mathrm{~s}^{-1}$. At the end of 15 days, the survivor plants were considered acclimatized and the parameters evaluated were analyzed again after rooting. The experimental design was completely randomized and the variance analyses (ANOVA) were compared by the Scott \& Knott test's at 5\% probability (FERREIRA, 2011).

\section{RESULTS AND DISCUSSION}

The bioreactors are an alternative to the viability the micropropagation technique of several species, especially by eliminating and/or automating some steps of the plant propagation (OLIVEIRA et al., 2011). However, studies comparing different semisolid and liquid medium are scarce. On the experiment of shoot multiplication on semisolid medium, the isolated meristems explants $( \pm 1 \mathrm{~mm})$ had survival rate of $91.66 \%$ and the meristems with adjacent tissue $( \pm 2.5 \mathrm{~mm})$ explants had survival rate of $83.33 \%$ after 60 days. On the other hand, the meristem with adjacent tissue produced more shoots/explant (6.49) compared with isolated meristem (3.18) (Table 1). Gao et al. (2013), reported that cutting the rhizome explants into $10 \mathrm{~mm}$ segments was better for massive shoot formation of Cymbidium sinense than cutting into $2.5 \mathrm{~mm}$ and $5 \mathrm{~mm}$ explant segments.

Moreover, the variance analysis showed 
significant difference $(p \leq 0.05)$ between the meristem source and the cultivation time for the variable average shoot number (Table 1). The regression analysis of the shoot total number by cultivation time was linear, showing the increasing of shoots during the cultivation, with average of 8.25 shoots/explant after 60 days (Figure 2).

The organogenic events occur by cellular differentiation, dedifferentiation and redifferentiation, depending on the resumption of the meristematic activity in the mature cells (MENDONÇA et al., 2012) from the adjacent tissue. The meristem with adjacent tissue of Eucalyptus camaldulensis may have higher levels of endogenous cytokinin, that acts in the cell division and the cell dedifferentiation and redifferentiation promoting and stimulating the shoot initiation and bud developments (MÜLLER; LEYSER, 2011). In addition to the cytokines, the relationship between the concentration of auxin-cytokinin is particularly important during patterning the shoot primordium and the shoot meristem (BESNARD et al., 2011; CHENG et al., 2013). This relationship leads to proper patterning of the expression of key regulatory genes, determining the organization of the developing shoot meristem (MOTTE et al., 2014). The endogenous hormone concentration will depend, among other factors, on the growth regulator concentration in the culture medium, the type and size of the explant (MOTTE et al., 2014). The size and the cell numbers of meristems zones of Eucalyptus grandis $\times$ Eucalyptus urophylla varied according to physiological age and the plastochron phase and these zones were significantly different between in vitro mature and in vitro juvenile plants (MANKESSI et al., 2011). This difference can reflect the organogenic potential of the meristem with adjacent tissue in promoting shoot proliferation on Eucalyptus camaldulensis explants. Aggarwal et al. (2012) observed, in the Eucalyptus tereticornis culture, that the number of shoots proliferated were significantly higher when larger shoot clumps (1520 shoots) were inoculated, compared to smaller shoot clumps (4-5 shoots).

About the shoot multiplication in bioreactors, the experiment with the continuous immersion bioreactor under different lighting conditions did not show significant differences for the average shoot number (Table 2), while showed significant difference for the bud numbers and the shoot lengths. The CIBD presented better results, with average of 6 buds/explants and an average of $4.38 \mathrm{~cm}$ shoot length than the CIBL system that had the average of 2.52 buds/explants and average of 1.76 of shoot length.

At the 60 days, it was observed on the CIBD, elongated shoots with multiple green light buds and on the CIBL smaller, oxidized and hyperhydric explants. The hyperhydricity is considered a physiological, biochemistry and morphologic disorder due to abnormal accumulation of water inside the cells and tissues. According to Vasconcelos et al. (2012), the physiological changes occur in major metabolic pathways including photosynthesis, respiration and transpiration, resulting in reduced efficiency of these metabolic pathways and are related to physical factors like the environment of cultivation and the culture medium.

Another characteristic observed in explants cultured on the CIBL system were translucent stems, less green, easily breakable and shorter internodes. Hyperhydricity is not restricted to shoots and the environmental factors, such as culture medium aeration, flow control, quality and light intensity and photoperiod can influence the growth and development of explants (OLIVEIRA et al., 2011), and the light has a major influence on the growth, development and morphogenesis of plants (MCALISTER et al., 2005).

On this CIBL system, the culture medium

TABLE 1: Average shoot number formed on isolated meristems $(1 \mathrm{~mm})$ and on meristems with adjacent tissue $(2.5 \mathrm{~mm})$ of Eucalyptus camaldulensis, 60 days after the cultivation.

TABELA 1: Número médio de brotos formados em meristemas isolados $(1 \mathrm{~mm})$ e meristemas com tecido adjacente $(2,5 \mathrm{~mm})$ de Eucalyptus camaldulensis aos 60 de cultivo.

\begin{tabular}{lc}
\hline \multicolumn{1}{c}{ Explants } & Shoot number \\
\hline Isolated meristems $( \pm 1 \mathrm{~mm})$ & $3.18 \mathrm{a}$ \\
Meristems with adjacent tissue $( \pm 2.5 \mathrm{~mm})$ & $6.49 \mathrm{~b}$ \\
\hline Em &
\end{tabular}

Em que: Means followed by different letters, in the column, statistically different by Scott \& Knott test $(p \leq 0.05)$. 


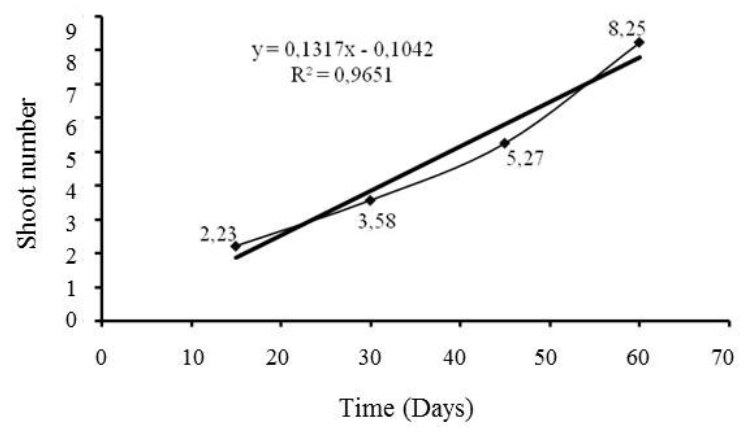

FIGURE 2: Regression analysis of Eucalyptus camaldulensis total shoot during 60 days of cultivation in semisolid medium.

FIGURA 2: Análise de regressão da formação total de brotos de Eucalyptus camaldulensis durante 60 dias de cultivo em meio de cultura semissólido.

also had grayish brown color and this changes in the CIBL culture medium color were due to phenolic compounds produced by the explant exposure to the light. The light leads also changes on culture medium $\mathrm{pH}$ affecting directly the absorption of nutrients (GEORGE et al., 2008) resulting on oxidation and abnormal morphogenesis. This condition, associated with the light intensity, causes an increased stress on the plants leading to the formation of plant products, including both primary and secondary metabolites (ZONG et al., 1991; SHOHAEL, 2006). It is widely believed that the synthesis of secondary metabolites in plants is part of the defense responses of plants to stress (MITTLER et al., 2001). As a result of stress, there is an immediate formation of reactive oxygen species (ROS) such as hydrogen peroxide $\left(\mathrm{H}_{2} \mathrm{O}_{2}\right)$, superoxide anions ( $\left.\mathrm{O}^{-}\right)$and hydroxyl free radicals $(\mathrm{OH})$ that trigger the plant signal systems. When in excess, ROS can result in the oxidation of proteins, unsaturated fatty acids and DNA, causing cellular damage and eventually, the cell death (SHOHAEL, 2006).

For the influence of the explant source in the bioreactor shoot multiplications, there was no significant difference on the shoot averages between explants excised from multiplied meristems (EMCIBD) (1.76 shoots average) and explants subcultured from continuous immersion on bioreactors (ESCIBD) (2.00 shoots average) (Table 3). On the other hand, EMCIBD showed the best results for the average bud numbers and shoot lengths, being 2 times (2.57) and 5 times (3.52) greater than ESCIBD, respectively (Table 3).

There was no difference in oxidation and culture medium consumption between the systems, but after 15 days the ESCIBD explants presented hyperhydricity on explants subcultured from continuous immersionon bioreactors (ESCIBD) and this may have been caused by the long contact with the culture liquid medium that leads the abnormal accumulation of water inside the cells and tissues (OLIVEIRA et al., 2014) 4, 8 and $16 \mathrm{~h}$.

The continuous immersion bioreactor in the dark (CIBD) and the temporary immersion bioreactor in the dark (TIBD) did not had statistically difference for the analyzed parameters. However, the CIBD system showed a tendency to promote the shoot differentiation, having the highest average number of shoots (2.38), while the TIBD system showed a tendency to promote the bud formations and elongation, having the highest values for average bud numbers (2.57) and shoot lengths (3.52) (Table 4). This result can be explained because the temporary immersion system provides a highly aerobic system for the plant growth, as there is forced ventilation through the vessel lid, however

TABLE 2: Average of shoot numbers, bud numbers and shoot lengths of Eucalyptus camaldulensis explants cultivated in bioreactor systems with different irradiance conditions.

TABELA 2: Número médio de brotos, número médio de gemas e comprimento dos brotos de explantes de Eucalyptus camaldulensis cultivados em biorreatores em diferentes condições de irradiância.

\begin{tabular}{lccc}
\hline \multicolumn{1}{c}{ Treatment } & Shoot number & Bud number & Shoot length $(\mathrm{cm})$ \\
\hline $\begin{array}{l}\text { Continuous immersion bioreactors in the dark } \\
\text { (CIBD) }\end{array}$ & $3.52 \mathrm{a}$ & $6.00 \mathrm{~b}$ & $4.38 \mathrm{~b}$ \\
$\begin{array}{l}\text { Continuous immersion bioreactors under light } \\
(\mathrm{CIBL})\end{array}$ & $2.76 \mathrm{a}$ & $2.52 \mathrm{a}$ & $1.76 \mathrm{a}$ \\
\hline
\end{tabular}

Em que: Means followed by different letters, in the column, statistically different by Mann-Whitney test $(p \leq 0.05)$. 
TABLE 3: Average of shoot numbers, bud numbers and shoot lengths of Eucalyptus camaldulensis from different explant sources.

TABELA 3: Número médio de brotos, gemas e comprimento de brotos de diferentes fontes de explantes de Eucalyptus camaldulensis.

\begin{tabular}{lccc}
\hline \multicolumn{1}{c}{ Treatment } & Shoot numbers & Bud numbers & Shoot lengths (cm) \\
\hline $\begin{array}{l}\text { Explants sub-cultured from continuous } \\
\text { immersion on bioreactors (ESCIBD) }\end{array}$ & $2.00 \mathrm{a}$ & $1.19 \mathrm{a}$ & $0.74 \mathrm{a}$ \\
$\begin{array}{l}\text { Explants excised from multiplicated } \\
\text { meristems (EMCIBD) }\end{array}$ & $1.76 \mathrm{a}$ & $2.57 \mathrm{~b}$ & $3.52 \mathrm{~b}$ \\
\hline $\begin{array}{l}\text { Em que: Means followed by different letters, in the column, statistically different by Mann-Whitney test }(p \leq 0.05) .\end{array}$
\end{tabular}

Em que: Means followed by different letters, in the column, statistically different by Mann-Whitney test $(p \leq 0.05)$.

the immersion times, the duration and frequency of the immersion are the most decisive parameter for a successful micro-propagation (BERTHOULY; ETIENNE, 2002; WATT, 2012), as they influence nutrient and water uptake and consequently hyperhydricity of the cultured material.

On the temporary immersion bioreactor experiment, the aeration lasted 15 min every 2 hours (Figure 1). McAlister et al. (2005), reported that the flush time interval of 20 min resulted in the lowest multiplication rate and it was found that the $5 \mathrm{~min}$ rest period gave significantly lower multiplication i.e., from 2.1 times ( $30 \mathrm{~s}$ flush) to 1.5 times at 10-minute flush and 10-minute flush time with a 5-minute resting period, the Eucalyptus clone shoots became brittle and the hyperhydricity occurred. Shaika et al. (2010), observed that a large number of micropropagated Lessertia frutescens shoots from the continuous immersion bioreactor $(80 \%)$ and from the temporary immersion bioreactor $(50 \%)$ showed thick broad leaves that were wrinkled and/or curled and brittle, symptoms of hyperhydricity. Oliveira et al. (2011), observed that the interval of a 2-hour immersion promoted higher fresh weight and bud numbers on Eucalyptus camaldulensis, but the hyperhydricity was a limiting factor. Oliveira et al. (2014), working with effect of frequency of immersion and air injection on the in vitro multiplication of Eucalyptus grandis $\mathrm{x}$ Eucalyptus urophylla reported that the immersions in every two and four hours and the filter paper showed higher growth and number of shoots, but caused a greater percentage of hyperhydric shoots. On Eucalyptus camaldulensis, it was not observed hyperhydricity due the long rest time, but the flush time can be improved to promote a successful micropropagation. Kim et al. (2010), working with commercially Eucalyptus clones suggest that plantlet growth increases with appropriate exposure to media at correct intervals, as well as the use of net for maintaining aerobic condition in the vessels. Comparing the meristems culture on solid medium (first experiment) and the CIBD system, it is possible to verify the similar multiplication. For commercial production, it is very important to increase the multiplication rate and yield reducing cost with biorreactor system using less physical space and manpower specialized by the decrease

TABLE 4: Average of shoot numbers, bud numbers and shoot lengths of Eucalyptus camaldulensis explants cultivated in a temporary and continuous immersion in a bioreactor.

TABELA 4: Número médio de brotos, gemas e comprimento do maior broto de explantes de Eucalyptus camaldulensis cultivados em biorreator de imersão temporária e contínua.

\begin{tabular}{lccc}
\hline \multicolumn{1}{c}{ Treatment } & Shoot number & Bud number & Shoot length (cm) \\
\hline $\begin{array}{l}\text { Temporary immersion bioreactor in the } \\
\text { dark (TIBD) }\end{array}$ & $1.76 \mathrm{a}$ & $2.57 \mathrm{a}$ & $3.52 \mathrm{a}$ \\
$\begin{array}{l}\text { Continuous immersion in bioreactors in } \\
\text { the dark (CIBD) }\end{array}$ & $2.38 \mathrm{a}$ & $1.85 \mathrm{a}$ & $3.51 \mathrm{a}$ \\
\hline
\end{tabular}

Em que: Means followed by different letters, in the column, statistically different by Mann-Whitney test $(p \leq 0.05)$. 
of handling material. The CIBD system had the highest multiplication rate as this system started with 21 explants and after 15 days presented 126 normal explants, meaning that each explant multiplied 6 times on average, using only one bottle for cultivation (Table 5).

Reis et al. (2003), working with Eucalyptus grandis $x$ Eucalyptus urophylla multiplication on RITA $^{\circledR}$ bioreactor and semisolid medium obtained an increase of 8 times in the fresh weight and 2.5 times in the shoot lengths in RITA ${ }^{\circledR}$ bioreactor. McAlister et al. (2005) found promising results in the cultivation of Eucalyptus clones in RITA ${ }^{\circledR}$ system, and obtained better results than those found in cultivation in the medium containing agar, with the highest rate of multiplication in RITA $^{\circledR}$ and the extensive proliferation of shoots from 14 to 18 days, while in the agar system, the multiplication was achieved only 25 to 28 days of cultivation.

The root initiation was observed after 10 days and the elongation was observed after 30 days of the inoculation, when the roots had the length between 0.5 to $7.0 \mathrm{~cm}$. Comparing the treatments with growth regulator in the dark and under light conditions, it was observed that except for T7 (2 mg $\mathrm{L}^{-1}$ IBA under light), all the dark treatments (Table 6) had higher rooting percentage. Concerning the average root number and main root length, there was no significant difference between the auxin concentration and the light condition. The largest root numbers/explants (5.6) occurred under light control treatment (T6) and in the dark when microcuttings were inoculated in culture medium with $8 \mathrm{mg} \mathrm{L}^{-1}$ of IBA (T4) and when the micro-cuttings were pretreated on $20 \mathrm{mg} \mathrm{L}^{-1}$ IBA for 12 hours (T5) (Table 6). When comparing the control treatments (T1 and T6), it was observed a dark period trend to induce longer roots $(2.7 \mathrm{~cm})$ (Table 6$)$, indicating that on free-growth regulator culture medium the dark is required for root elongations.

The average seedling lengths was the only variable that showed significant difference for IBA concentrations. The best results were observed in the explants maintained under light condition without IBA (T6) and with $8 \mathrm{mg} \mathrm{L}^{-1}$ IBA (T9), with an average length of $6 \mathrm{~cm}$ and $5.9 \mathrm{~cm}$, respectively. For the dark condition, the treatment with $8 \mathrm{mg} \mathrm{L}^{-1}$ IBA (T4), showed the best results, with average growth of $4.7 \mathrm{~cm}$ (Table 6). In all the treatments, it was not observed callus at the micro-cutting bases. About the explant rooting, when comparing the treatments in the dark and under light conditions, it was observed that the dark treatments had the best results with higher rooting percentage. Assis e Teixeira (1998), report the importance of the shoots exposure to a dark period to improve the rooting. The

TABLE 5: Total bud number/treatment and multiplication rate of Eucalyptus camaldulensis in different bioreactor systems and in semisolid medium, 15 days after the inoculation.

TABELA 5: Número total de gemas/tratamento e taxa de multiplicação de Eucalyptus camaldulensis 15 dias após a inoculação em diferentes sistemas de biorreatores e em meio semissólido.

\begin{tabular}{|c|c|c|c|}
\hline Treatment & $\begin{array}{c}\text { Initial explant } \\
\text { number }\end{array}$ & $\begin{array}{l}\text { Total bud } \\
\text { number/ } \\
\text { treatment }\end{array}$ & Multiplication rate \\
\hline Semisolid medium - Isolated meristems & 24 & 76 & 3.18 \\
\hline $\begin{array}{l}\text { Semisolid medium }- \text { Meristems with } \\
\text { adjacent tissue }\end{array}$ & 24 & 156 & 6.49 \\
\hline Continuous immersion in the dark - CIBD & 21 & 126 & 6.00 \\
\hline $\begin{array}{l}\text { Continuous immersion under the light - } \\
\text { CIBL }\end{array}$ & 21 & 53 & 2.52 \\
\hline Temporary immersion in the dark - TIBD & 21 & 54 & 2.57 \\
\hline Continuous immersion in the dark - CIBD & 21 & 39 & 1.86 \\
\hline $\begin{array}{l}\text { Explants sub-cultured from bio-reactor - } \\
\text { ESCIBD }\end{array}$ & 21 & 25 & 1.19 \\
\hline $\begin{array}{l}\text { Explants excised from meristems - } \\
\text { EMCIBD }\end{array}$ & 21 & 54 & 2.57 \\
\hline
\end{tabular}


dark exposure shows direct or indirect effect on the production of sugar, auxin, phenols and endogenous enzymes that leads the rooting. Moreover, the light reduction can promote stem etiolation, which stimulates the adventitious root inductions (BRIAN; BASSUL, 1998). Considering the growth regulator IBA, the highest percentages of rooting $(100 \%)$ were observed on culture medium without IBA maintained in dark and in culture medium with $2 \mathrm{mg}$ $\mathrm{L}^{-1}$ of IBA maintained on light. According to Smet e Beeckman (2011), the adventitious root initiations involves the meristematic cell niche formations (initial cells and/or target cells) which are dependent on external and internal factors. The differentiation of the meristematic cells niche and the formation of new roots involve the stem tissue disruptions to form connections with the conductive vascular tissues (LI et al. 2009; BRONDANI et al., 2012) induced by auxins. Brondani et al. (2011) working with Eucalyptus benthamii x Eucalyptus dunnii observed that the $1 / 2$ MS culture medium suplemeted with $1 \mathrm{mg} \mathrm{L}^{-1}$ IBA induced $75 \%$ of micro-cuttings rooting. Bunn (2005), observed efficiency of $73 \%$ on Eucalyptus impensa micro-cutting rootings when the explants were subjected to a combination of $0.45 \mathrm{mg} \mathrm{L}^{-1} \mathrm{NAA}$ and $0.058 \mathrm{mg} \mathrm{L}^{-1} \mathrm{IBA}$. According to Souza e Pereira (2007), the most common auxins used for rooting are NAA, IBA and IAA. The main differences among them are the molecule structure and the stability, where NAA is more stable than IAA, thus, most of the in vitro rooting works use NAA and IBA auxins. But, the result found in this work suggests that Eucalyptus camaldulensis possibly has sufficient endogenous auxin that consequently, leads the rooting (WAREING; PHILLIPS, 1981).

Regardless the auxin formula, the excessive concentration in the culture medium can be toxic, promoting callus formation at the micro-cutting bases, compromising rooting and shoot growths. Generally, the root and shoot vascular concentration is very fragile and the callus formation can compromise the adventitious root functionality (LI et al., 2009), but it was not observed callus formation on explants of Eucalyptus camaldulensis. Based on these results, the treatments in the dark, without growth regulator, are considered the most suitable for in vitro rooting of Eucalyptus camaldulensis, by providing $100 \%$ of rooting without growth regulator in the culture medium, leading to a cost reduction in the process.

All the rooted explants, in the previous experiments, were transferred to acclimatization. Thus, 67 explants were acclimatized on a mist chamber for 15 days, and after that, it was observed $76 \%$ of survival (Figure $3 \mathrm{~A}$ ). Before transferring the seedlings to ex vitro conditions, they had an average shoot size of $4.2 \mathrm{~cm}$ and 13.8 leaves/seedlings and after that, they had an average shoot size of $5 \mathrm{~cm}$ and 9.7 leaves/seedlings. The leaves had deep green color and did not wither during acclimatization, indicating that the plants suffered little stress in the acclimatization process due to the high humidity in the mist chamber, which allowed the leaves remain humid, reducing the transpiration rate and avoiding

TABLE 6: Rotting percentage, average of root number, leaf numbers, main length root $(\mathrm{cm})$ and seedling lengths $(\mathrm{cm})$ of Eucalyptus camaldulensis in different concentrations of auxin $(0,2,4,8 \mathrm{e}$ $20 \mathrm{mg} \mathrm{L}^{-1}$ IBA). Treatments (T1-T5) maintained for 15 days in the dark. Treatment (T6-T9) conducted in a photo-period of 16 hours for 30 days.

TABELA 6: Porcentagem de enraizamento, número médio de raízes, folhas, comprimento médio da maior raiz $(\mathrm{cm})$ e comprimento médio das plantas $(\mathrm{cm})$ de Eucalyptus camaldulensis cultivados em diferentes concentrações de auxinas (0, 2, 4, 8 e $\left.20 \mathrm{mg} \mathrm{L}^{-1} \mathrm{AIB}\right)$. Tratamentos (T1-T5) mantido por 15 dias no escuro. Tratamento (T6-T9) mantido por 30 dias em fotoperíodo de 16 horas.

\begin{tabular}{lccccccccc}
\hline \multirow{2}{*}{ Variable } & \multicolumn{4}{c}{ Dark } & \multicolumn{4}{c}{ Light } \\
\cline { 2 - 9 } & $0 \mathrm{mg} \mathrm{L}$ & $2 \mathrm{mg} \mathrm{L}^{-1}$ & $4 \mathrm{mg} \mathrm{L}^{-1}$ & $8 \mathrm{mg} \mathrm{L}^{-1}$ & $20 \mathrm{mg} \mathrm{L}^{-1}$ & $0 \mathrm{mg} \mathrm{L}^{-1}$ & $2 \mathrm{mg} \mathrm{L}^{-1}$ & $4 \mathrm{mg} \mathrm{L}^{-1}$ & $8 \mathrm{mg} \mathrm{L}^{-1}$ \\
\hline Rootiong (\%) & 100 & 70 & 70 & 90 & 80 & 50 & 100 & 50 & 60 \\
Root number & $2.4 \mathrm{a}$ & $2.7 \mathrm{a}$ & $4.5 \mathrm{a}$ & $5.6 \mathrm{a}$ & $5.6 \mathrm{a}$ & $5.6 \mathrm{a}$ & $4.7 \mathrm{a}$ & $2.8 \mathrm{a}$ & $5.1 \mathrm{a}$ \\
Main root length & $2.7 \mathrm{a}$ & $1.5 \mathrm{a}$ & $2.8 \mathrm{a}$ & $3.5 \mathrm{a}$ & $1.3 \mathrm{a}$ & $1.4 \mathrm{a}$ & $3.5 \mathrm{a}$ & $3.5 \mathrm{a}$ & $2.7 \mathrm{a}$ \\
Seedling lengths & $3.3 \mathrm{a}$ & $3.7 \mathrm{a}$ & $3.9 \mathrm{a}$ & $4.7 \mathrm{a}$ & $4.0 \mathrm{a}$ & $6 \mathrm{~b}$ & $4.5 \mathrm{a}$ & $4.1 \mathrm{a}$ & $5.9 \mathrm{~b}$ \\
Leaf numbers & $13 \mathrm{a}$ & $12 \mathrm{a}$ & $12 \mathrm{a}$ & $13 \mathrm{a}$ & $17 \mathrm{a}$ & $15 \mathrm{a}$ & $15 \mathrm{a}$ & $13 \mathrm{a}$ & $14 \mathrm{a}$ \\
\hline
\end{tabular}

Em que: Means followed by different letters, in the line, statistically different by Scott \& Knott $(p \leq 0.05)$. 
the plant dehydration (Figure $3 \mathrm{~B}$ and $\mathrm{C}$ ).

In the acclimatization, $76 \%$ of the explants survived, but the in vitro plants with a single root were unable to survive when transferred to ex vitro conditions. These species do not have great ability to rooting ex vitro micro-cutting, as the single in vitro root died and the others were not originated. According to Debergh e Maene (1981), only in some species, the roots produced in vitro are functional and do not die when transferred to ex vitro conditions. The transplantation success is determined by the root system obtained in vitro and shorter roots are the most suitable exhibiting active growth phase and facilitating the plant survival, as demonstrated in this work. The long roots length causes further damage when the seedlings are removed from the culture medium and transplanted into substrate.

It was observed that, after acclimatization, there was a reduction in the number of leaves and this decreasing was probably due to the natural cycling nutrients which may have been used for growth. The leaves are important during the acclimatization because the use of active photo-synthetically radiation stimulates the photosynthesis, epicuticular wax deposition and water uptake (LEITE et al., 2000) leading the nutrient absorption, increasing the seedlings survival. Bennett e Mccomb (1982), acclimatized Eucalyptus marginata explants in a greenhouse with gradually reduced humidity, and

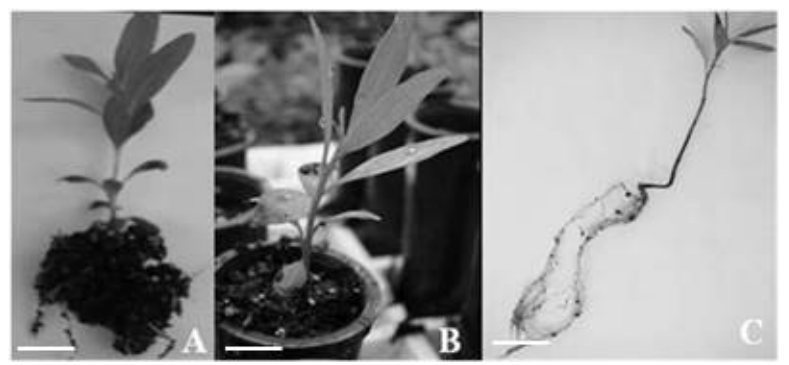

FIGURE 3: Acclimatization process in mist chamber of Eucalyptus camaldulensis clones rooted in vitro. A - Plants after 15 days of acclimatization. $\mathrm{B}$ and $\mathrm{C}$ Plants after 45 days of acclimatization. (Barr $5 \mathrm{~mm}$ ).

FIGURA 3: Processo de aclimatização em plantas de Eucalyptus camaldulensis enraizadas in vitro. A - Plantas depois de 15 dias de aclimatização. B e C - Plantas depois de 45 de aclimatização. (Barra $5 \mathrm{~mm}$ ). after 4 weeks found $50 \%$ of survival. Bandeira et al. (2007), woking with Eucalyptus grandis x Eucalyptus urophylla grafted in vitro, observed $87 \%$ of survival.

These results demonstrate that using the mist chamber obtained a high index of survival and provided an effective metabolism.

\section{CONCLUSIONS}

On semisolid medium, the meristem with adjacent tissue favored a greater number of buds/ explants.

The continuous immersion bioreactors in the dark provided higher shoots number and multiplication rate.

For Eucalyptus camaldulensis in vitro rooting, the culture medium without auxin and kept in the dark for 15 days or the culture medium supplemented with auxin $2 \mathrm{mg} \mathrm{L}^{-1}$, maintained under light provided $100 \%$ plantlet rooting.

The species Eucalyptus camaldulensis can be micropropagated using as explants, the meristematic tissue and the bioreactor system.

\section{ACKNOWLEDGMENT}

This research was financially supported by the following Brazilian agencies: Foundation for Supporting Research in the state of Minas Gerais (FAPEMIG), Coordination for the Improvement of Higher Level - or Education - Personnel (CAPES) and National Council for Scientific and Technological Development (CNPq).

\section{REFERENCES}

AGGARWAL, D. et al. Factors affecting micropropagation and acclimatization of an elite clone of Eucalyptus tereticornis Sm. In Vitro Cellular \& Developmental Biology - Plant, New York, v. 48, n. 5, p. 521-529, 2012.

ANDRADE, W. F.; ALMEIDA, M.; GONÇALVES, N. A. Multiplicação in vitro de Eucalyptus grandis sob estímulo com benzilaminopurina. Pesquisa Agropecuária Brasileira, Brasília, v. 41, n. 12, p. 1715-1719, 2006.

ASSIS, T. F.; FETT-NETO, A. G.; ALFENAS, A. C. Current techniques and prospects for the clonal propagation of hardwoods with emphasis on Eucalyptus. In: WALTER, C.; CARSON, M. (Ed.). Plantation Forest Biotechnology for the 21st 
Century. Trivandrum: Research Signpost, 2004. p. 303-333.

ASSIS, T. F.; TEIXEIRA, S. L. Enraizamento de plantas lenhosas. In: TORRES, A. C.; CALDAS, L. S.; BUSO, J. A. (Ed.) Cultura de tecidos e transformação genética de plantas. [s. 1.]: EMBRAPA-SPI /EMBRAPA-CNPH,1998. p. 61-296

BANDEIRA, F. S. et al. Aclimatização ex vitro de plantas pela enxertia in vitro de clones de Eucalyptus urophylla x E grandis. Revista Árvore, Viçosa, v. 31, n. 5, p. 73-781, 2007.

BARTLETT, M. S. Properties of sufficiency and statistical tests. In: ROYAL SOCIETY OF LONDON PROCEEDINGS SERIES A, 1937. Proceedings... 1937. p. 268-282.

BENNETT, I. J.; MCCOMB, J. A. Propagation of Jarrah (Eucalyptus marginata) by organ and tissue culture. Australian Forestry, Australia, v. 12, n. 6, p. 121-127, 1982.

BERTHOULY, M.; ETIENNE, H. Temporary immersion system: a new concept for use of liquid medium in mass propagation. In: INTERNATIONAL SYMPOSIUM ON LIQUID SYSTEMS FOR IN VITRO MASS PROPAGATION OF PLANTS, 1. 2002, Norway. Proceedings... Norway: Cost 843 Working Group, 2002. p. 37-38

BESNARD, F; VERNOUX, T.; HAMANT, O. Organogenesis from stem cells in planta: multiple feedback loops integrating molecular and mechanical signals. Cellular and Molecular Life Sciences, New York, v. 68, n. 2, p. 885-906, 2011.

BINKLEY, D. et al. The Brazil Eucalyptus potential productivity project: influence of water, nutrients and stand uniformity on wood production. Forest Ecology and Management, Netherlands, v. 259, n. 9, p. 1684-1694, 2010.

BRIAN, K. M.; BASSUK, N. L. Etiolation and banding effects on adventitious root formation In: DAVIS, T.D.; HAISSIG, B.E.; SANKHLA, N. (ed). Adventitious root formation in cuttings. New York: [s. n.], 1988. v. 2, p. 30-46.

BRONDANI, G. E. et al. Micropropagation of an Eucalyptus hybrid (Eucalyptus benthamii $\mathrm{x}$ Eucalyptus dunnii). Acta Scientiarum. Agronomy, Maringá, v. 33, n. 4, p. 655-663, 2011.

BRONDANI, G. E. et al. Low temperature, IBA concentrations and optimal time for adventitious rooting of Eucalyptus benthamii mini-cuttings. Journal of Forestry Research, New York, v. 23, n. 4, p. 583-592, 2012.

BUNN, E. Development of in vitro methods for ex situ conservation of Eucalyptus impensa, an endangered mallee from southwest Western Australia. Plant Cell Tissue Organ Culture, New York, v. 83, n. 1, p. 97-102, 2005.

CHENG, Z. J. et al. Pattern of auxin and cytokinin responses for shoot meristem induction results from the regulation of cytokinin biosynthesis by AUXIN RESPONSE FACTOR3. Plant Physiology, Rockville, v. 161, n. 1, p. 24051, 2013.

DEBERGH, P. C.; MAENE, L. J. A scheme for the commercial propagation of ornamental plants by tissue culture. Science Horticulture, Amsterdan, v. 14, n. 4, p. 335-334, 1981.

FERREIRA, D. F. Sisvar: a computer statistical analysis system. Ciencia e Agrotecnologia, Lavras, v. 35, n. 6, p. 1039-1042, 2011.

GAO, R. et al. Micropropagation of Cymbidium sinense using continuous and temporary airlift bioreactor systems. Acta Physiologiae Plantarum, New York, v. 36, n. 1, p. 117-124, 2013.

GEORGE, E. F.; HALL, M. A.; DE KLERK, G. J. (Eds.) Plant Propagation by Tissue Culture. 3th ed. Dordrecht: Springer-Verlag, 2008. v. $1,502 \mathrm{p}$.

GONÇALVES, J. et al. Assessing the effects of early silvicultural management on long-term site productivity of fast-growing eucalypt plantations: the Brazilian experience. Southern Forests: a Journal of Forest Science, London, v. 70, n. 2, p. 105-118, 2008.

HU, W. J. et al. Repression of lignin biosynthesis promotes cellulose accumulation and growth in transgenic trees. Nature Biotechnoly, Berlin, v. 17, p. 808-812, 1999.

KIM, S. J. G. N. S. M. G. et al. Use of the Temporary Immersion Bioreactor System for Mass Production of Eucalyptus pellita Plus Tree. Journal of Korean Forestry Society, South Korea, 2010.

KOMATSU, Y. H. et al. In vitro morphogenic response of leaf sheath of Phyllostachys bambusoides. Journal of Forestry Research, New York, v. 22, n. 2, p. 209-215, 2011.

LEITE, G. B.; FINARDI, N.; FORTES, G. R. L. Efeitos de concentrações de sacarose no meio de cultura e da intensidade luminosa no enraizamento in vitro do portaenxerto de pereira $\mathrm{OH} X \mathrm{X} 97$. Ciência e Agrotecnology, Lavras, v. 24, n. 2, p. 353-357, 2000.

LI, S. W. et al. Mediators, genes and signaling in adventitious rooting. Botanycal Review, New York, v. 75, n. 2, p. 230-247, 2009.

LIMA, G. P. P. et al. Polyamines, Gelling Agents 
in Tissue Culture, Micropropagation of Medicinal Plants and Bioreactors. In: LEVA, A. (Ed.). Recent Advances in Plant in vitro Culture. [s.l: s.n., 2011]. Available from: <http://www.intechopen. com/books/recent-advances-in-plant-in-vitroculture/polyamines-gelling-agents-in-tissueculture-micropropagation-of-medicinal-plants-andbioreactors $>$.

MANKESSI, F. et al. Histocytological characteristics of Eucalyptus urophylla $\times$ Eucalyptus grandis shoot apical meristems of different physiological ages. Trees, New York, v. 25, n. 3, p. 415-424, 2011.

MCALISTER, B. et al. Use of the temporary immersion bioreactor system $\left(\right.$ RITA $\left.^{\circledR}\right)$ for production of commercial Eucalyptus clones in Mondi Forests (SA). Plant Cell, Tissue and Organ Culture, New York, v. 81, n. 3, p. 347-358, 2005.

MENDONÇA, E. G. et al. Growth curve and development of the internal calli structure of Eucalyptus camaldulensis Dehn. Brazilian Archives of Biology and Technology, Curitiba, v. 55, n. 6, p. 887-896, 2012.

MOTTE, $H$. et al. The molecular path to in vitro shoot regeneration. Biotechnology Advances, Amsterdam, v. 32, n. 1, p. 107-121, 2014.

MÜLLER, D.; LEYSER, O. Auxin, cytokinin and the control of shoot branching. Annals Botany, Oxford, v. 107, n.7, p. 1203-1212, 2011.

MURASHIGE, T.; SKOOG, F. A revised medium for rapid growth and bioassays with tobacco tissue cultures. Physiology Plant, Amsterdam, v. 15, n. 3, p. 473-497, 1962.

OLIVEIRA, M. L. et al. Efeitos do meio de cultura e da relação BAP/ANA na multiplicação in vitro de clones de Eucalyptus grandis x E. urophylla em biorreator de imersão temporária. Revista Árvore, Viçosa, MG, v. 35, n. 6, p. 1207-1217, 2011.

OLIVEIRA, M. L. et al. Efeito do intervalo de imersão e de injeção de ar na multiplicação in vitro de Eucalyptus grandis $x$ Eucalyptus urophylla em biorreator de imersão temporária. Ciência Florestal, Santa Maria, v. 24, n. 1, p. 37-45, 2014.

PASSOS, I. R. S. et al. Cultura in vitro de meristemas de videira: I concentrações do hormônio 6-BA em meio primário. Bragantia, Campinas, v. 44 , n. 1 , p. 473-479, 1985.

REIS, J. P. et al. Micropropagação de eucalipto no sistema de imersão temporária. In: CONGRESSO BRASILEIRO DE CULTURA DE TECIDOS DE PLANTAS, 2003, Lavras. Anais...Lavras: UFLA, 2003. $276 \mathrm{p}$.
SHAIKA, S. et al. Micropropagation and bioreactor studies of the medicinally important plant Lessertia (Sutherlandia) frutescens. South Africa Journal of Botany, Pretoria, v. 76, n. 2, p. 180-186, 2010.

SHAPIRO, S. S.; WILK, M. B. An analysis of variance test for normality (complete sample). Biometrika, Oxford, v. 52, n. 3, p. 591-611, 1965. SHOHAEL, A. M. Effect of light on oxidative stress, secondary metabolites and induction of antioxidant enzymes in Eleutherococcus senticosus somatic embryos in bioreactor. Process Biochemistry, Amsterdam, v. 41, n. 2, p. 1179-1185, 2006.

SILVA, A. B. et al. Métodos de micropropagação de abacaxizeiro. Pesquisa Agropecuária Brasileira, Brasília, v. 42, n. 9, p. 1257-1260, 2007.

SMET, I.; BEECKMAN, T. Assymmetric cell division in land plants and algae: the driving force for differentiation. Nature Reviews Molecular Cell Biology, Berlin, v. 12, n. 3, p. 177-188, 2011.

SOUZA, A. V.; PEREIRA, M. A. S. Enraizamento de plantas cultivadas in vitro. Revista Brasileira de Plantas Medicinais, Paulínia, v. 9, n. 4, p. 103-117, 2007.

STAPE, J.; BINKLEY, D.; RYAN, M. G. Eucalyptus production and the supply, use and efficiency of use of water, light and nitrogen across a geographic gradient in Brazil. Forest Ecology and Management, Amsterdam, v. 193, n. 1, p. 17-31, 2004.

TAKAYAMA, S.; AKITA, M. The types ofbioreactors used for shoots and embryos. Plant Cell, Tissue and Organ Culture, New York, v. 39, n. 2, p. 147-156, 1994.

TANTOS, Á. et al. Triacontanol-sipported micropropagation of woody plans. Plant Cell Reports, New York, v. 20, n. 1, p. 16-21, 2001.

TOURNIER, V. An efficient procedure to stably introduce genes into an economically important pulp tree (Eucalyptus grandis, Eucalyptus urophylla). Transgenic Research, New York, v. 124, n. 2, p. 403-411, 2003.

VASCONCELOS, A. G. V. et al. Hiperidricidade: uma desordem metabólica. Ciência Rural, Santa Maria, v. 42, n. 5, p. 837-844, 2012.

XAVIER, A.; COMÉRCIO, J. Microestaquia: uma maximização da micropropagação de Eucalyptus. Revista Árvore, Viçosa, MG, v. 20, n. 1, p. 9-16, 1996.

XAVIER, A.; WENDLING, I. Miniestaquia na clonagem de Eucalyptus. Viçosa: SIF, 1998. 10 p. WAREING, P. F.; PHILLIPS, I. D. J. Growth and differentiation in plants. 3th ed. Oxford: Pergamon, 
1981. $343 \mathrm{p}$.

WATT, M. P. The status of temporary immersion system (TIS) technology for plant micropropagation. African Journal Biotechnology, Ebène, v. 11, n. 76, p. 14025-14035, 2012.
WATT, M. P. Genotypic-unspecific protocols for the commercial micropropagation of Eucalyptus grandis $\times$ nitens and E. grandis $\times$ urophylla. Turkish Journal of Agriculture and Forestry, Ankara, v. 38, n. 1, p. 125-133, 2014. 